\title{
Correction to: Identity Strategies of Stateless Ethnic Minority Groups in Contemporary Poland
}

\author{
Ewa Michna and Katarzyna Warmińska
}

\section{Correction to:}

E. Michna and K. Warmińska (eds.), Identity Strategies

of Stateless EthnicMinority Groups in Contemporary Poland,

Migration, Minorities and Modernity 5, https://doi.org/10.1007/978-3-030-41575-4

The original version of the book was inadvertently published with incomplete text in all chapters, which has now been updated and approved by the editor. The chapters and the book corrections now has been updated with changes 